SCIENTIFIC COMMUNICATION

\title{
EFFECT OF THE ENTOMOPATHOGENIC NEMATODE STEINERNEMA GLASERI (RHABDITIDA: STEINERNEMATIDAE) ISOLATE SANTA ROSA ON THE BIOLOGICAL PARAMETERS OF ENGORGED NYMPHS OF AMBLYOMMA CAJENNENSE (ACARI: IXODIDAE)
}

\section{R. Cardoso ${ }^{1}$, C. M.O. Monteiro' ${ }^{2}$, M.C.A. Prata ${ }^{3}$, E.S.P. Batista ${ }^{4}$}

${ }^{1}$ Universidade Federal de Juiz de Fora. Rua José Lourenço Kelmer, s/nº, CEP 36036-330, Juiz de Fora, MG, Brasil.

\begin{abstract}
This work evaluated the in vitro effects of Steinernema glaseri on the biology of engorged Amblyomma cajennense nymphs. The ticks were exposed to infective juveniles (IJs) of S. glaseri at different concentrations. Each treatment was composed by 10 experimental units (EU = repetitions) in Petri dishes maintained at $27 \pm 1^{\circ} \mathrm{C}$ and relative humidity $(\mathrm{RH})>80 \pm 10 \%$ for 72 hours. Then the nymphs were transferred to Petri dishes free of nematodes for observation of the following parameters: pre-ecdysis period $(P E P)$, ecdysis period $(E P)$, molting period $(\mathrm{MP})$, ecdysis percentage (\%Ec) and mortality percentage (\% Mt). The groups treated with 5,000 and 10,000 IJs/EU showed significant alterations in the PEP when compared to the control, while for the EP only the treatment with $10,000 \mathrm{IJs} / \mathrm{EU}$ produced any significant changes compared to the control. The MP did not differ significantly from the control in any of the treated groups. For the \% Ec only the group treated with 10,000 IJs/EU differed significantly from the control. The greatest efficiency was obtained at the concentration of $10,000 \mathrm{IJ} / \mathrm{EU}$, in which the mortality percentage was $13 \%$. This demonstrates that the nematode utilized was not able to cause high mortality in engorged A. cajennense nymphs and agrees with other reports indicating that immature ticks are not highly susceptible to entomopathogenic nematodes.
\end{abstract}

KEY WORDS: Cayenne tick, entomopathogenic nematode, microbial control.

\section{RESUMO}

OS EFEITOS DO NEMATOIDE ENTOMOPATOGÊNICO STEINERNEMA GLASERI (RHABDITIDA: STEINERNEMATIDAE) ISOLADO SANTA MARIA SOBRE OS PARÂMETROS BIOLÓGICOS DE NINFAS INGURGITADAS DE AMBLYOMMA CAJENNENSE (ACARI: IXODIDAE). Esse trabalho avaliou os efeitos in vitro de Steinernema glaseri sobre a biologia de ninfas ingurgitadas de Amblyomma cajennense. Os carrapatos foram expostos a juvenis infectantes (JI) de $S$. glaseri sob diferentes concentrações. Cada tratamento foi composto de 10 unidades experimentais (EU $=$ repetições) em placas de Petri mantidas sob $27 \pm 1^{\circ} \mathrm{C}$ e UR $>80 \pm 10 \%$ por 72 horas. Em seguida, as ninfas foram transferidas para placas de Petri isentas de nematoides para observação dos seguintes parâmetros: período de pré-ecdise (PPE), período de ecdise (PE), período de muda (PM), porcentagem de ecdise $(\% E c)$ e porcentagem de mortalidade $(\% M t)$. Os grupos tratados com 5.000 e $10.000 \mathrm{JI} / \mathrm{UE}$ mostraram alterações significativas no PPE quando comparados com o controle, enquanto para o PE somente o tratamento com $10.000 \mathrm{JI} / \mathrm{UE}$ produziu mudanças significativas quando comparado com o controle. Não houve diferença significativa do PM em relação ao grupo controle em nenhum dos tratamentos e, para a \% Ec, somente o grupo tratado com $10.000 \mathrm{JI} / \mathrm{UE}$ diferiu significativamente do controle. A maior eficiência foi obtida com a concentração de 10.000 JI/EU na qual a mortalidade foi de $13 \%$. Isso demonstra que o nematoide utilizado não foi capaz de causar alta mortalidade em ninfas ingurgitadas de A. cajennese e concorda com outros relatos indicando que carrapatos imaturos não são altamente susceptíveis a nematoides entomopatogênicos.

PALAVRAS-CHAVE: Carrapato estrela, nematoide entomopatogênico, controle microbiano.

${ }^{2}$ Universidade Federal Rural do Rio de Janeiro, Seropédica, RJ, Brasil.

${ }^{3}$ Embrapa Gado de Leite, , Juiz de Fora, MG, Brasil.

${ }^{4}$ Universidade Estadual Paulista, Faculdade de Ciências Agrárias e Veterinárias, Jaboticabal, SP, Brasil. 
The Cayenne tick, Amblyomma cajennense (Fabricius, 1787) is widely distributed in Brazil. It is one of the main species that afflict horses (OliveirA, 2004), and can also afflict other hosts, including humans, due to its low parasitic specificity (GUIMARÃES et al., 2001). This tick is of great economic importance because of the damage it causes to herds, such as blood spoliation and cutaneous lesions (PRATA, 2005). A. cajennense is also of great public health concern because it is the main tick that attacks humans in the Neotropical region and the principal vector of the bacterium Rickettsia rickettsii, the etiological agent of Brazilian spotted fever (GueDEs et al., 2005).

Efforts to control this tick generally involve the use of synthetic chemical acaricides. Although they are effective in killing the ticks, they generate residues that are harmful to the environment, and when used inappropriately can cause intoxication of animals and humans (PRATA, 2005). Therefore, the exclusive use of chemical is not advisable in the medium and long term in both economic and environmental terms (CAPALBO; DE NARDO, 2000), making it necessary to find effective alternatives as part of integrated management systems.

A promising alternative in the biological control of these arthropods is the use of entomopathogenic nematodes (EPNs) of families Steinenermatidae and Heterorhabditidae. Studies have been shown that different tick species are susceptible to infection by EPNs (Hill, 1998; KaAyA et al., 2000; FreitasRibeiro et al., 2009; Monteiro et al., 2010). These nematodes act as vehicles of highly pathogenic bacteria, which when introduced into the host's body cause rapid septicemia, leading to death (HAzIR et al., 2003). KocAn et al. (1998) demonstrated that engorged females of $A$. cajenense were susceptible to infection by Steinernema riobrave (CABANILLAS et al., 1994); however, EPNs have not been tested against other stages of this tick.

Studies of the biological control of ticks using EPNs are still sparse, particularly ones investigating the influence of these nematodes on the biological parameters of engorged nymphs. The aim of this study, then, was to evaluate the effect of different concentrations of the entomopathogenic nematode Steinernema glaseri (Steiner, 1929), strain Santa Rosa, on the biological parameters of engorged nymphs of $A$. cajennense.

Engorged nymphs of A. cajennense were used from a colony maintained through artificial infestation on rabbits Oryctolagus cuniculus (Linnaeus, 1758), according to the method proposed by NeITZ et al. (1971). The nematodes were multiplied in last instar caterpillars of Galleria mellonella Linnaeus, 1958 (Pyralidae, Lepdoptera) according to the method proposed by КАҮA; Sтоск (1997).
For preparation of suspensions, it was counted ten aliquots of $10 \mu \mathrm{L}$ obtained from $30 \mathrm{~mL}$ aqueous suspension of nematodes stored in cell culture bottle of $40 \mathrm{~mL}$. Then we calculated the mean of infective juveniles (IJs) per sample and from this average, the suspensions were adjusted for concentrations utilized.

Each experimental unit (EU) was composed of 10 engorged nymphs placed in Petri dish $(10 \mathrm{~cm}$ in diameter) containing sifted and sterilized sand, as proposed by ZHIOUA et al. (1995). The following concentrations were tested: 0 (control group), 156, $325,675,1,250,2,500,5,000$ and 10,000 infective $S$. glaseri juveniles per EU. Each treatment was composed by 10 EUs (repetitions).

Every group was sprayed with $4 \mathrm{~mL}$ per experimental unit containing the mentioned nematode concentrations and then the Petri dishes were sealed with parafilm and kept in a climatecontrolled chamber at $27 \pm 1^{\circ} \mathrm{C}$ and relative humidity (RH) $>80 \pm 10 \%$ for 72 hours. After this, the nymphs were washed in distilled water and transferred to new Petri dishes for daily monitoring to observe the following biological parameters: pre-ecdysis period (PEP), the period from rec overy of the engorged instar until the day of the first ecdysis or molting in each dish; ecdysis period (EP), from ecdysis of the first and the last specimen in each dish; molting period $(M P)$, from collection of the engorged nymphs until all specimens had reached the adult phase in each $\mathrm{EU} ;$ ecdysis percentage $(\% \mathrm{Ec})$, the total number of that had undergone ecdysis in relation to the total number of specimens in each EU; and mortality percentage (\% $\% \mathrm{Mt}$ ) given by subtracting $100 \%$ minus the $\%$ Ec, since specimens that did not undergo ecdysis died.

It was used the Graphpad Instat Version 2.05 software for the statistical analysis. The data in percentages were transformed into $\sqrt{\arcsin x}$. The mean parameter values for each treatment were analyzed by ANOVA and the Tukey test $(p<0.05)$. When the data were not normally distributed, the parameters were compared by the nonparametric Kruskal Wallis and Dunn tests $(p<0.05)$.

The groups treated with 5,000 and 10,000 IJs/EU had average PEPs of 12 and 14 days, respectively, differing significantly $(p<0.05)$ from the same period for the control group, which was 13.3 days. In other words, at the concentration of 5,000 IJs/ EU the pre-ecdysis period was shorter than in the control group, while at the higher concentration of $10,000 \mathrm{IJ} / \mathrm{EU}$ it was longer. The ecdysis period of the group treated with 10,000 IJs/EU was 2.3 days, differing significantly $(p<0.05)$ from the figure for the control group, which was 4.3 days. With respect to this parameter, there were no significant 
differences between the other treatments and the control (Table 1).

There were also no significant differences for the molting period between the control group and any of the ones treated with different concentrations of $S$. glaseriIJs. Theecdysis percentage of thegroupsubmitted to $10,000 \mathrm{IJ} / \mathrm{EU}$ was $87 \%$, differing significantly (p $<0.05$ ) from the control group, in which $98 \%$ of the nymphs underwent ecdysis. The \%Ec of the other treated groups ranged between $95 \%$ and $97 \%$, with no significant differences in relation to the control group. The mortality caused by the action of the nematodes in the different treatments was small, reaching 13\% at the highest concentration (10,000 IJs/EU) (Table 1).

Various studies have indicated that entomopathogenic nematodes are promising agents to control ticks (Reis-MeninI et al., 2008; FreItAs-Ribeiro et al., 2009; MONTEIRO et al., 2010), but some works have demonstrated that larvae and both engorged and unfed nymphs are less susceptible to the action of these nematodes than are engorged adult females (ZhIOUA et al.,1995; HiLL, 1998; KaAYA et al., 2000). This can explain the results obtained in the present study, since only the highest concentration of nematodes per Petri dish caused significant changes in the biological parameters of engorged A. cajennense nymphs, and none of the concentrations tested resulted in high mortality; while KocANetal. (1998) reported mortality of $88 \%$ for engorged females of $A$. cajennense treated with $S$. riobrave at concentration of 5,000 IJs/tick.

SAMISH et al. (1996) reported that immature Rhipicephalus annulatus Say, 1821, Hyalomma excavatum Koch, 1844, Rhipicephalus bursa Canestrini and Fanzago, 1878 and Rhipicephalus sanguineus Latreille, 1806 , ticks were resistant to Steinernema carpocapsae (Weiser, 1955), isolate DD. ZHIOUA et al. (1995) found that the nematodes $S$. carpocapsae and S. glaseri were pathogenic to engorged females of Ixodes scapularis Say, 1821, but they were not to larvae and engorged nymphs of this same tick, a fact also observed by HILL (1998). Evaluating the efficiency of different nematode isolates on some ticks, KAAYA et al. (2000) also concluded that the immature stages were more resistant than adults and that only nymphs of Rhipicephalus evertsi Neumann, 1897 were moderately susceptible to $S$. carpocapsae DD, since the use of this nematode caused $40 \%$ of the nymphs to die. The resistance of immature ticks can be attributed to the absence of genital pores, while engorged adult females have everted genital pores, facilitating their penetration of the host (ZHIOUA et al., 1995; SAMISH et al., 1996). EPNs of the genus Steinernema Travassos, 1927 depend on openings to penetrate their host's body, unlike species of the genus Heterorhabditis Poinar, 1976, which can actively penetrate the host's body with their chitinous tooth located in the anterior region (DOLINSKI, 2006).

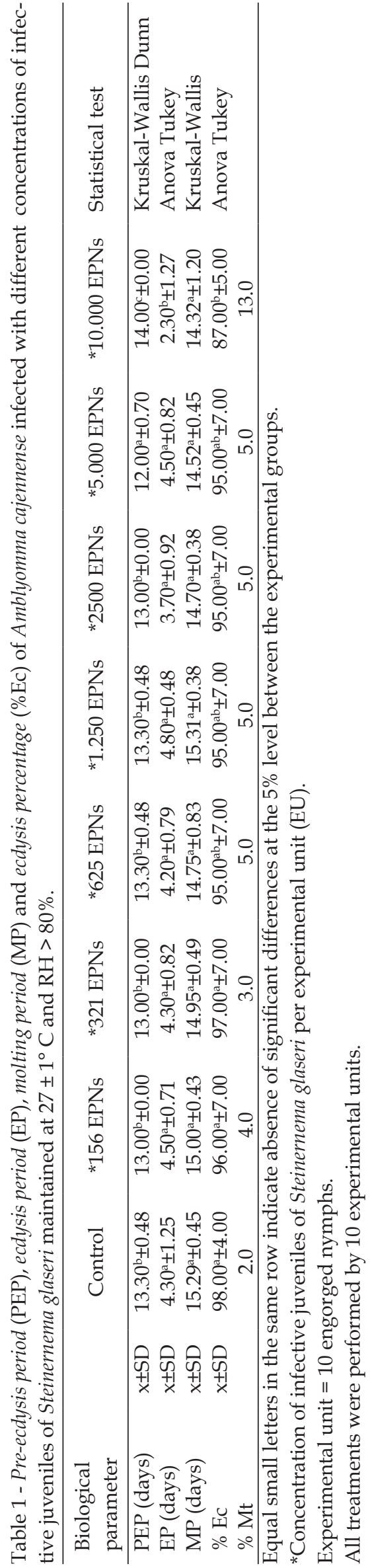


KAAYA et al. (2000) also found that engorged females of the genus Amblyomma were more resistant to nematodes than engorged females of other genus. These various findings suggest that not only are nymphs more resistant to infections by EPNs, ticks of the genus Amblyomma are also more resistant, explaining the low mortality in the present study. Another possibility is that some ticks can produce cuticular secretions that repel or kill nematodes (MAULÉON et al., 1993).

The nematode has low virulence for nymphs of $A$. cajennense, causing low mortality rates, however, it was observed that treatments with higher concentrations altered the pre-ecdysis and ecdysis period, showing there was slight interference in those biological parameters.

Therefore, further studies are necessary to evaluate the efficiency of entomopathogenic nematodes on $A$. cajennense adults and the use of other EPN species and isolates in tests with immature individuals of this tick species, since the pathogenicity can vary according to the genus, species and strain of the nematode tested (HiLl, 1998; KaAyA et al., 2000; Monteiro et al., 2010). Future studies can reveal new possibilities to develop ecologically friendly non-chemical methods to control this tick, to replace or reduce the use of chemical pesticides.

\section{ACKNOWLEDGEMENTS}

To CNPq and FAPEMIG for financial support to research.

\section{REFERENCES}

CABANILLAS, H.E.; POINAR; G.O.; RAULSTON, R. Steinernema riobravis n.sp. (Rhabditida: Steinermatidae) from Texas. Fundamental and Applied Nematology, v.17, p.123-131, 1994.

CAPALBO, D.M.F.; DE NARDO, E.A.B. Análise de risco e impacto ambiental do uso de agentes de controle biológico. In: MELO, I.S.; AZEVEDO, J.L. (Ed.). Controle biologico. Jaguariúna: EMBRAPA Meio Ambiente, 2000. p.351-385.

DOLINSKI, C. Uso de nematoides entomopatogenicos para o controle de pragas. In: VENZON. M.; PAULA, JÚNIOR, T.J.; PALLINI, A. (Org.). Tecnologias alternativas para o controle alternativo de pragas e doenças. Viçosa: EPAMIG, 2006. p.261-289.

FREITAS-RIBEIRO, G.M.; VASCONCELOS, V.O.; FURLONG, J.; DOLINSKI, C. Evaluation of the efficacy of strains of Steinernema carpocapsae Santa Rosa and all (Steinernematidae: Rhabditida) to control engorged female Anocentor nitens (Acari: Ixodidae). Parasitology Research, v.104, p.1203-1206, 2009.
GUEDES, E.; LEITE, R.C.; PRATA, M.C.A.; PACHECO, R.C.; WALKER, D.H.; LABRUNA, M.B. Detection of Rickettsia rickettsii in the tick Amblyomma cajennense in a new Brazilian spotted fever-endemic area in the state of Minas Gerais. Memórias do Instituto Oswaldo Cruz, v.100, p.841-848, 2005.

GUIMARÃES, J.H.; TUCCI, E.C.; BARROS-BATESTI, D.M. Ectoparasitos de importância médico veterinária. São Paulo: Plêiade/FAPESP, 2001. 213p.

HAZIR, R.S.; KAYA, H.K.; STOCK, P.; KESKIN, N. Entomopatogenic nematodes (Steinernematidae and Heterorhabditidae) for biological control of soil pests. Turkish Journal of Biology, v.27, p.181-202, 2003.

HILL, D.E. Entomopathogenic nematodes as control agents of developmental stages of the black legged tick, Ixodes scapularis. Journal of Parasitology, v.84 p.1124-1127, 1998.

KAAYA, G.P.; SAMISH, M.; GLAZER, I. Laboratory evaluation of pathogenicity of entomogenous nematodes to African ticks species. Annals of the New York Academy of Sciences, v.916, p.306-308, 2000.

KAYA, H.K.; STOCK, P. Techniques in insect nematology. In: LACEY, L.A. (Ed.) Manual of techniques in insect pathology. San Diego: Academic Press, 1997. p.281-324.

KOCAN, K.M.; BLOUIN, E.F.; PIDHERNEY, M.S.; CLAYPOOL, P.L.; SAMISH, M.; GLAZER, I. Interaction of entomopathogenic nematodes (Steinernematidae) with selected species of ixodid ticks (Acari: Ixodidae). Journal of Medical Entomology, v.35, p.514-520, 1998.

MAULEON, H.; BARRE, N.; PANOMA, S. Pathogenicity of 17 isolates of entomophagous nematodes (Steinernematidae and Heterorhabditidae) for the ticks Amblyomma variegatum (Fabricius), Boophilus microplus (Canestrini) and Boophilus annulatus (Say). Experimental Applied Acarology, v.17, p.831-838, 1993.

NEITZ, W.O.; BOUGHTON, F.; WALTERS, H.S. Laboratory investigations on the life caroo paralysis tick Ixodes rubidicundus (Neumann, 1904). Journal of Veterinary Research, v.38, p.215-224, 1971.

MONTEIRO, C.M.O.; FURLONG, J.; PRATA, M.C.A.; SOARES, A.E.; BATISTA, E.S.P.; DOLINSKI, C. Evaluation of the action of Heterorhabditis bacteriophora (Rhabditida: Heterorhabditidae) isolate HP88 on the biology of engorged females of Rhipicephalus (Boophilus) microplus (Acari: Ixodidae). Veterinary Parasitology, v.170, p.355358, 2010.

OLIVEIRA, P.R. Biologia e controle de Amblyomma cajennense. Revista Brasileira de Parasitologia Veterinária, v.23, p.118-122, 2004.

PRATA, M.C.A. Carrapato estrela: problemas e soluções para animais e humanos. In: FURLONG, J. Carrapato: 
problemas e soluções. Juiz de Fora: Embrapa Gado de Leite, 2005. p.51-65.

REIS-MENINI, C.M.R.; PRATA, M.C.A.; FUROLNG, J.; SILVA, E.R. Compatibility between the entomopathogenic nematode Steinernema glaseri (Rhabditida: Steinernematidae) and an acaricide in the control of Rhipicephalus (Boophilus) microplus (Acari: Ixodidae). Parasitology Research, v.2, p.1391-1396, 2008.

SAMISH, M.I.; GLAZER, I.; ALEKSEEV, E.A. The susceptibility of the development stages of ticks (Ixodidae) to entomopathogenic nematodes. In:
RODGER, M.; HORN, D.J.; NEEDHAM, G.R.; WELBOURN, W.C. (Ed.). Acarology IX. Columbus: Ohio Biological Survey, 1996. p.121-123.

ZHIOUA, E.; LEBRUN, R.A.; GINSEBERG, H.S.; AESCHLIMANN, A. Pathogenicity of Steinernema carpocapse and S. glaseri (Nematoda: Steinernematidae) to Ixodes scapularis (Acari: Ixodidadae). Journal of Medical Entomology, v.32, p.900-905, 1995.

Received on $21 / 11 / 11$

Accepted on 16/04/13 